\title{
Biogenic Amines and Microbiological Profile of Egyptian Cheeses
}

\author{
Khaled Meghawry El-Zahar \\ Food Science Department, Faculty of Agriculture, Zagazig University, 44511 Zagazig, Egypt \\ *Correspondence author: k.elzahar@yahoo.com
}

Copyright (c) 2014 Horizon Research Publishing All rights reserved.

\begin{abstract}
Cheeses are among those high-proteincontaining foodstuffs in which enzymatic and microbial activities cause the formation of biogenic Amines (BAs) from amino acids decarboxylation. Most of the methods for amine determination in these products involve acid extraction followed by a liquid-liquid purification step to selectively separate amines and amino acids. This study aimed to describe the development of biogenic amines in Egyptian cheeses during ripening and storage regimes. Biogenic Amines content in Mish, Ras and Blue cheeses were 270-1300, 340-980 and 210-700 mg/kg, respectively. The dominant Biogenic Amines were different. This work confirms that the main biological feature influencing amines formation is the extent of growth of microorganisms, like enterococci, characterized by decarboxylase activity. It is important to report that the presence of biogenic amines due to the activities of these microorganisms is maintained within safe levels. In Egypt, reports deals with the Egyptian cheeses (Mish, Ras and Blue) are scanty. So, the present work was carried out to fill the gap in our knowledge on its microbiological and biochemical features, focusing on hygiene and consumer health aspects.
\end{abstract}

Keywords Biogenic Amines, Food Safety, Proteolysis, Ripening, Enterococci spp

\section{Introduction}

Milk and milk products are very important in human nutrition and, among them; cheese is considered a good source proteins, vitamins and minerals. However, cheese is one of the most fermented foods commonly associated with BAs contamination. These compounds are basic nitrogenous compounds formed by series of microorganisms, mainly by decarboxylation of amino acids or "in vivo" also by de-amination and trans-amination of aldehydes and ketones [Loizzo et al., 2012]. Biogenic Amines are compounds commonly present in living organisms in which they are responsible for many essential functions. They can be naturally present in many foods such as fruits and vegetables, meat, fish, chocolate and milk, but they can also be produced in high amounts by microorganisms through the activity of amino acid decarboxylases [Ten Brink et al., 1990]. Excessive consumption of these amines can be of health concern because they're not equilibrate assumption in human organism can generate different degrees of diseases determined by their action on nervous, gastric and intestinal systems and blood pressure [Suzzi \& Gardini, 2003]. Biogenic amines are low molecular weight nitrogenous bases, they were found in fermented foods and cheese [Mohamed et al., 2013].

Also, biogenic amines are low-molecular nitrogenous compounds that are formed in foodstuffs mainly by microbial decarboxylation of the precursor amino acids [Alberto et al., 2002]. The importance of observing BAs content lies in potential toxicity to human, mainly when the concentration is up to $100 \mathrm{mg} / \mathrm{kg}$ (or up to $100 \mathrm{mg} / \mathrm{L}$ ). Thus, the presence of BAs significantly influences the food quality and safety [Smit et al., 2005].

The presence of relevant amounts of BAs in cheeses has been documented [Martuscelli et al., 2005; Kung et al., 2007; Pintado et al., 2008; Ladero et al., 2009; Mercogliano et al., 2010]. In cheeses BAs formation is caused by curdling and cheese decarboxylase-positive microorganisms. Histamine (HIS), tyramine (TYR), putrescine (PTR), cadaverine (CAD), spermidine (SPD), spermine (SPR), tryptamine (T), and $\beta$-phenylethylamine (PE) are frequently found in these products. Cheese is one of the fermented foods most commonly associated with BAs poisoning; mainly HIS, TYR, PTR and CAD. Indeed, the term "cheese reaction" has been coined to refer to it [Ten Brink et al., 1990]. Tyramine and histamine are the most abundant and frequent BAs in cheese [Fernández et al., 2007]. Consumption of food containing high levels of BAs is considered undesirable since it can be associated with several toxicological problems such as respiratory distress, headache, hyper- or hypo-tension or allergies [Ladero et al., 2010]. These problems are especially severe in consumers with low levels of the enzymes involved in the detoxification system (mono and di-amine oxidases), either by genetic disorders [Caston et al., 2002] or medical treatments (Halász et al., 1994).

Physiologically, histamine is one of the most effective 
BAs; it has vasoactive and psychoactive effects [Repka-Ramirez \& Baraniuk, 2002]. Moreover, it is the main BAs involved in food poisoning and the only it that is limited in some foodstuffs by law. At non-toxic doses, food borne histamine can cause intolerance symptoms such as diarrhoea, hypotension, headache, pruritus, and flushes. Just $75 \mathrm{mg}$ of histamine, a quantity commonly present in some meals, can induce symptoms in the majority of healthy persons with no history of histamine intolerance [Wöhrl et al., 2004].

The production of BAs in cheese has been mainly attributed to the activity of non-starter microorganisms, even if an indirect role of starter lactic acid bacteria cannot be excluded. Generally, the main amine found was tyramine, followed by putrescine and cadaverine [Novella-Rodriguez et al., 2002]. Enterococci $s p$. commonly occurs in raw milk and dairy products. Milk is an ideal source for the growth of these organisms. Enterococci $s p$. may be present in substantial numbers in cheese curd and ripened cheeses. Many researchers have also reported their presence in pasteurized and UHT milk and investigated the survival upon milk processing [Garg \& Mital, 1992; Cogan et al., 1997]. The ability of microorganisms to decarboxylate amino acid is highly variable. Due to strain-specific, it is important to count decarboxylase-positive microorganisms to estimate; the risk of BAs food content and to prevent BAs accumulation in food products. Presence and accumulation of BAs depends on many factors such as presence of specific bacteria (Enterococci, Micrococci, Enterobacteriaceae and Lactobacilli) and enzymes, availability of free amino acids, presence of suitable cofactors, i.e. $\mathrm{pH}$ level, water activity, temperature and salt content, type of cheese, ripening and storage period [Galgano et. al., 2001]. Some controversial results have been reported on the contribution of Enterococci $s p$ in BAs production in cheeses, and in particular in histamine [Sumner \& Taylor, 1989]. Enterococci have a long history of use as artisanal cultures for preparation of various types of cheeses [Izquierdo et. al., 2009], they are sometimes associated with pathogenicity [Khan et. al., 2010], who reported to be the cause of endocarditic, bacteraemia, and several infections, as well as of multiple antibiotic resistances [Kayser 2003]. Although the chemical composition and microbiological quality of cheeses in Egyptian markets have been studied extensively, little data is available on the occurrence of biogenic amines in Egyptian cheeses. Therefore, this survey was undertaken to determine the presence of BAs in commercially available cheeses during ripening and storage, also to make an assessment of the health hazard arising from the consumption of these products especially by susceptible individuals. This study aimed to describe the development of selected BAs (cadaverine, histamine, $\beta$-phenyl ethylamine, putrescine, tryptamine, tyramine, spermidine, and spermine) in Egyptian cheeses depending on ripening/storage regimes) and to review hypothesis that the BAs content develops during the ripening and storage period is related to the presence of Enterococci spp.

\section{Materials and Methods}

\subsection{Cheese Samples}

A total 85, 49 and 44 of Mish, Ras and Blue cheeses samples were purchased from different Egyptian retail markets and small scale factories. The samples collected were 6-48 months old. It were kept in sterile plastic bags and transported to the laboratory at Food science Department, Zagazig University (Egypt), then stored at 4 $\pm 1^{\circ} \mathrm{C}$ until analyzed.

\subsection{Chemical Analyses}

Cheeses were analyzed in triplicates for moisture by the oven drying method at $102^{\circ} \mathrm{C}$ [IDF, 1993], salt by titration with $\mathrm{AgNO}_{3}$, and fat by Gerber method [AOAC, 2002]. For $\mathrm{pH}$ measurement, grated cheese $(10 \mathrm{~g})$ was macerated with $10 \mathrm{~mL}$ of distilled water and the $\mathrm{pH}$ of the resultant slurry was measured using a digital $\mathrm{pH}$ meter $(\mathrm{pH} 211$, Hanna Instruments, Vila do Conde, Portugal). Titratable acidity was determined as $\mathrm{g}$ lactic acid $/ 100 \mathrm{~g}$ cheese is using the method of AOAC [2002].Total volatile fatty acids and total nitrogen (TN) using the methods of AOAC [2002]. All analyses were carried out in triplicates.

\subsection{Assessment of Proteolysis}

\subsubsection{Nitrogen Fractions}

Water-soluble nitrogen fraction (WSN) of cheese was prepared according to Kuchroo and Fox [1982] and a cheese to water ratio of $1: 5$ was used. $12 \%$ trichloroacetic acid soluble nitrogen-fraction (TCA-SN, i.e. NPN) was obtained by mixing equal volumes of water-soluble fraction and $24 \%$ (w/w) TCA solution, followed by filtration through a white ribbon filter paper (Schleicher and Schuell, Dassel, Germany). The nitrogen content of both fractions (WSN and TCA-SN, respectively) was determined by Kjeldahl method [AOAC, 2002] and expressed as \% of (TN).

\subsubsection{Free Amino Acids and Biogenic Amines}

Free amino acids (FAA) and BAs were assayed according to the method of Krause et al., [1995], modified by Pinho et al., [2001]. In brief, a $4 \mathrm{~g}$ cheese sample was suspended in $15 \mathrm{~mL}$ of $0.2 \mathrm{M}$ aqueous perchloric acid; the mixture was homogenized in an Ultra Turrax blender (Sotel, Warsawa, Poland) for $2 \mathrm{~min}$, then kept in an ultrasonic bath (Heraeus, Osterode, Germany) for $30 \mathrm{~min}$, and finally centrifuged at $4000 x g$ / 20min. Derivatization was carried out via dabsyl chloride, at $70^{\circ} \mathrm{C}$ for $15 \mathrm{~min}$. The reaction was quenched by placing the vials in an ice bath for $5 \mathrm{~min}$. High performance liquid chromatography (HPLC, Waters 600) was used to dansylamines determination. The system equipped with delivery system, reverse phase $\mathrm{C}_{\mathrm{I}}$ Nucleosil column $250 \mathrm{x}$ $4 \mathrm{~mm}, 10 \mu \mathrm{m}$ packing (Macherey - Naggl). The detection was performed using U.V detector (Waters 486) at wavelength $254 \mathrm{~nm}$ using linear program of $25 \mathrm{~min}$ period 
and $1 \mathrm{ml} / \mathrm{min}$ constant solvent flow rate. Data were integrated and recorded using a Millennium Chromatography (Waters, Milford MA 01757). Elution was carried out at a flow rate of $1 \mathrm{~mL} / \mathrm{min}$, using a volumetric gradient of solution A $9 \mathrm{mM}$ aqueous sodium di-hydrogenophosphate, $4 \%$ (w/v) di-methyl formamide and $0.1 \%(\mathrm{w} / \mathrm{v})$ triethylamine (adjusted to $\mathrm{pH} 6.55$ with phosphoric acid), and solution B 80\% (v/v) aqueous acetonitrile. Detection was performed by measuring absorbance at $436 \mathrm{~nm}$. Quantification was carried out based on a mixture of amino acid standards: aspartic acid, glutamic acid, serine, threonine, glycine, alanine, arginine, proline, valine, methionine, isoleucine, leucine, tryptophan and phenylalanine; and biogenic amine standards: ornithine, lysine, histidine, tyrosine, ethylamine, dimethylamine, tryptamine, phenyl ethylamine, putrescine, cadaverine, histamine, tyramine, cystamine and spermine (Sigma Chemical). All determinations were performed in quadruplicate (Fig 1).

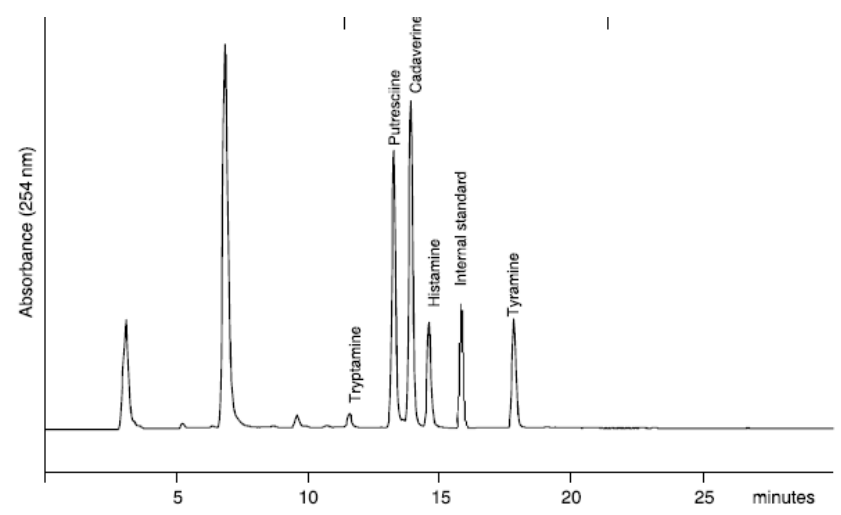

Figure 1. Histogram relative to the biogenic amine areas of a standard solution derivatized with incubation at $40^{\circ} \mathrm{C}$ for $40 \mathrm{~min}$

\subsection{Microbiological Analysis}

For each cheese sample, $10 \mathrm{~g}$ was weighed and dispersed aseptically in $90 \mathrm{~mL}$ of citrate buffer $(2 \%, \mathrm{w} / \mathrm{v})$ and homogenized in a sterile polyethylene bag using a Stomacher (Seward Laboratory Blender Stomacher 400Lab Blender UK) for $1.5 \mathrm{~min}$. Serial dilutions were made in $0.1 \%$ sterile peptone water and all determinations were made in triplicates (Messer et al. 1985). The enumeration of total mesophilic bacteria (Plate Count Agar, Merck, Germany) at $30^{\circ} \mathrm{C} / 48 \mathrm{~h}$, total coliform groups (Violet Red Bile Agar, Merck, Germany) at $37^{\circ} \mathrm{C}$ for $48 \mathrm{~h}$, yeasts and moulds (Potato Dextrose Agar, Merck, Germany) at $21^{\circ} \mathrm{C}$ for 7 days, Lactobacilli (MRS agar, Merck, Germany), Lactococcus sp (M17 agar, Merck, Germany) and Enterococci (Azide Dextrose agar, Merck, Germany) at $28^{\circ} \mathrm{C}$ for $48 \mathrm{~h}$ [Frank et al. 1993] were performed.

\subsection{Statistical Analysis}

The effect of time of ripening on all parameters of proteolysis and on total FAA and BAs content of the cheese was assessed by analysis of variance (ANOVA) using the SPSS 10.0 for Windows software [Liu et al., 2003].

\section{Results and Discussion}

\subsection{Evaluation of Physico-Chemical Parameters}

The chemical compositions of Egyptian cheeses were presented in Table (1). The total solids content of Cheese samples varied from 30.5 to $46.5,47.2$ to 58.3 and 41.2 to $48.8 \%$ in Mish, Ras and Blue cheeses, respectively. A significant variation of fat content was observed, 17.8-30.4; 33.8-48.3 and 25.3-38.4\% in Mish, Ras and Blue cheeses, respectively. The salt content of the Cheese samples fell within the range, 6.1-10.5; 5.6-6.8 and 4.5-5.7\% in Mish, Ras and Blue cheeses, respectively. Whereas, the $\mathrm{pH}$ of cheeses ranged from 4.2 to $5.3 ; 4.5-5.2$ and 4.9-5.8 respectively, which agrees with those reported for good quality Egyptian cheeses [Kebary et al., 1999; Ibrahim \& Amer, 2010]. Total nitrogen content in Cheese samples was slightly higher in Ras cheese compared to Mish and blue cheeses. Whilst, the water soluble nitrogen was lowest in Blue cheese compared with other cheeses (Table 1). The WSN/TN ratio showed differences in the degree of ripening of the component cheeses. Non-protein nitrogen represented more than $50 \%$ of the WSN of the tested cheeses; this may have originated from the component cheeses. WSN and NPN have been classically used as a measure of the extent of secondary proteolysis, i.e., formation of small sized peptides (2-20 residues) and free amino acids [Furtado \& Partridge, 1988]. Total volatile fatty acids showed a significant variation among the tested cheeses, 33.5-55.4; 62.7-92.7 and 45.6-74.5 as $0.1 \mathrm{NNaOH} / 100 \mathrm{~g}$, in Mish, Ras and Blue cheese, respectively. These variations indicated large differences in quality and degree of ripening in Egyptian cheeses. Production of BAs has frequently been referred to the proteolytic activity of microorganisms present in cheese during manufacture and ripening. Increases in the non-protein nitrogen fractions (WSN and NPN) often means levels increased of free amino acids, which are precursors of BAs.

\subsection{Amino Acids and BAs}

BAs content of cheese can be extremely variable and depends on the type of cheese, the ripening time, the manufacturing process and the microorganisms present [Ordònez et al., 1997]. The Egyptian cheeses (Mish, Ras and Blue) examined confirmed this variability in the total content of BAs ranging from 21.0 to $130.0 \mathrm{mg} / 100 \mathrm{~g}$ cheese (Table 2). There are significant differences among contents of the eight BAs assayed. Only the Mish cheese contained more than 100 $\mathrm{mg} / 100 \mathrm{~g}$ cheese of the total BAs, as affected by increasing the storage period. According to Taylor [1985], the threshold of risk is $100 \mathrm{mg} / \mathrm{kg}$ total amines of cheese, if ingestion is 
associated with such potentiating co-factors as amine oxidase-inhibiting drugs or alcohol, or else if there are pre-existing gastrointestinal diseases (Stratton et al., 1991). Production of BAs in cheese has often been associated with non-starter lactic acid bacteria and Enterobacteriaceae [Joosten \& Northolt, 1987], so it may be a toxicological risk associated with consumption of raw milk cheese, especially by sensitive individuals. Spanjer and van Roode [1991] suggested that the total concentration of tyramine, histamine, putrescine and cadaverine in cheese should not exceed 900 $\mathrm{mg} / \mathrm{kg} \mathrm{DW}^{-1}$, but no upper limit for BAs in cheese has been legally enforced.

Even if no significant differences were observed in the final amounts of BAs in Blue and Ras cheeses, the dynamics of accumulation were not the same. Overall, histamine was the most prevalent amine, being found in all analyzed Cheese samples. It was followed by tryptamine $(98 \%)$, putrescine (97\%), cadaverine $(95 \%)$, tyramine $(89 \%)$, spermidine (73\%), 2-phenylethylamine (72\%), and spermine (37\%). In spite of being the most frequently detected amine, spermine was present at low levels, below $2.5 \mathrm{mg} / 100 \mathrm{~g}$ cheese. Spermidine and $\beta$-phenyl ethylamine were also detected at low levels (below 4 and 12mg/100g cheese, respectively). However, histamine, cadaverine, tryptamine, putrescine and tyramine were detected at levels up to $30,21,20,19$ and 18 $\mathrm{mg} / 100 \mathrm{~g}$, respectively. Histamine was the most prevalent amine, it was found in all analyzed Cheese samples (Table 2). Higher means levels were detected for Mish, Ras and Blue cheeses (9-31, 12-26 and 4-14 mg/ 100g, respectively). Histamine levels capable of causing histamine poisoning were detected in all Cheese samples. However, taking into account the concomitant presence of polyamines, it is likely that a higher percentage of Cheese samples could cause histamine poisoning. Tyramine was present in $100 \%$ of Mish and Ras cheeses and in $60 \%$ of Blue cheese. Mish cheese $(53 \%)$ and Ras cheese (18\%) contained tyramine at levels capable of causing hypertensive crisis [Komprda et al., 2008]. Overall, tryptamine was detected sporadically, at lower amounts compared to histamine. Similar results were observed by Chang et al., [1985]. Higher means levels of tryptamine were observed in Mish and Ras cheeses. The toxic threshold of tryptamine is not known [Joosten, 1988]. $\beta$-Phenyle thylamine, another amine of health significance was detected $100 \%$ in Blue, $82 \%$ in Ras and $53 \%$ in Mish cheese. The prevalence of this amine was high, however the levels detected were low $(\leq 12 \mathrm{mg} / 100 \mathrm{~g})$, below its toxic threshold. The rate of cadaverine and tryptamine accumulation were similar for the traditional Mish and Ras cheeses to that described for the total BAs formation. The accumulation of amines increased remarkably later on in the ripening and storage periods. The rate of $\beta$-phenyl ethylamine accumulation was similar for Ras and Blue cheeses, whereas histamine and tryptamine values were higher in the Ras cheese and reached concentrations of 12 $26 \mathrm{mg} / 100 \mathrm{~g}$ and $10-20 \mathrm{mg} / 100 \mathrm{~g}$, respectively.

Similar results were obtained with heat treatment or bactofugation of the milk used for Emmental production and had little effect on the tyramine content [Krause et al., 1997]. The rates of spermine and spermidine accumulation were similar for Mish and Blue cheeses, whereas tryptamine and histidine were higher in the Mish cheeses and reached concentrations of $4-22$ and $9-31 \mathrm{mg} / 100 \mathrm{~g}$, respectively. According to Halász et al., [1994], Gouda cheese a long with Swiss and Cheddar cheeses, which contain high levels of BAs and are the most frequently incriminated cheese in histamine poisoning episodes.

Amino acid levels in cheeses types were extremely variable (Table 3 ). This fact was attributed to an accelerated amino acid release at the manufacturing day, when cheeses were incubated at temperatures favorable for microorganism development and activity [Bütikofer \& Fuchs, 1997]. Any food with free amino acids, especially tyrosine and phenylalanine, are subject to BAs formation if poor sanitation and low quality foods are used or if the food was subjected to temperature abuse or extended storage time [Schirone et al., 2011].

High variability was observed in $\mathrm{pH}$, acidity, moisture and fat contents of the different analyzed cheese types. Several analyzed samples did not meet the standard of identity and quality established by Egyptian legislation. With regard to quality parameters, $\mathrm{pH}$, moisture and fat content and acidity correlated significantly $(\mathrm{P} \leq 0.05)$ with formation and accumulation of some BAs. These results suggest that, the among quality parameters evaluated, acidity influenced amine formation in several cheese types. These results are supported by the theory that the formation of BAs is a protective mechanism of bacteria against acidic environments [Maijala, 1994]. The presence of micro-organisms with high decarboxylase activity has been reported as the main factor for BAs production in cheese. Moreover, some strains have proteolytic activity, which can affect the accumulation of BAs in cheese [Galgano et al., 2001]. For the production of amines, the enzymatic activity of proteases derived from micro- organisms, or from another origin, is important from a qualitative point of view, i.e., in relation to the type of amino acids provided to the amino acid decarboxylating microflora. The bacteriological composition of milk could be critical to define the amine profile in cheese; therefore, large amounts of amines in cheese could indicate unsuitability from a hygienic point of view, and the milk used for cheese making. Moreover, the results emphasize the necessity of controlling the indigenous bacterial population responsible for high production of BAs and the use of competitive adjunct cultures is suggested. 
Table 1. Chemical composition and proteolysis indices of Egyptian Cheese samples ripened/stored at different periods

\begin{tabular}{|c|c|c|c|c|c|c|c|c|c|c|c|}
\hline \multirow{2}{*}{$\begin{array}{l}\text { Cheese } \\
\text { types }\end{array}$} & \multirow{2}{*}{$\begin{array}{l}\text { Ripening/Storage } \\
\text { period (mon) }\end{array}$} & \multicolumn{6}{|c|}{ Physico-chemical parameters } & \multicolumn{4}{|c|}{ Proteolysis indices } \\
\hline & & $\begin{array}{c}\text { Total } \\
\text { Solid \% } \\
\end{array}$ & $\begin{array}{l}\text { Fat in } \\
\text { solid \% }\end{array}$ & $\begin{array}{c}\text { Protein in } \\
\text { solid \% }\end{array}$ & Acidity a & $\mathrm{pH}$ & $\begin{array}{l}\text { Salt in } \\
\text { solid \% }\end{array}$ & $\begin{array}{c}\text { Total } \\
\text { nitrogen \% }\end{array}$ & $\begin{array}{c}\text { Non-protein } \\
\text { nitrogen } \%\end{array}$ & $\begin{array}{c}\text { Water soluble } \\
\text { nitrogen } \%\end{array}$ & TVFAaa \\
\hline \multirow{5}{*}{ Mish } & 6 & $30.5 \pm 2.0^{\mathrm{d}}$ & $17.8 \pm 2.5^{\mathrm{d}}$ & $20.1 \pm 1.07^{\mathrm{a}}$ & $3.31 \pm 0.71^{\mathrm{a}}$ & $4.2 \pm 0.1^{\mathrm{d}}$ & $6.1 \pm 1.5^{\mathrm{b}}$ & $3.15 \pm 0.98^{\mathrm{a}}$ & $0.22 \pm 0.4^{\mathrm{b}}$ & $0.29 \pm 0.5^{\mathrm{d}}$ & $33.5 \pm 2.2 \mathrm{c}$ \\
\hline & 12 & $35.6 \pm 2.1^{\mathrm{c}}$ & $20.8 \pm 2.2^{\text {cd }}$ & $18.5 \pm 1.15^{\mathrm{b}}$ & $3.01 \pm 0.65^{\mathrm{b}}$ & $4.4 \pm 0.1^{\mathrm{cd}}$ & $7.2 \pm 1.6^{\mathrm{ab}}$ & $2.91 \pm 0.78^{\mathrm{a} b}$ & $0.31 \pm 0.6^{\mathrm{a}}$ & $0.34 \pm 0.6^{\text {cd }}$ & $40.5 \pm 2.5 \mathrm{~b}$ \\
\hline & 24 & $37.0 \pm 1.9^{\mathrm{b}}$ & $22.3 \pm 3.2^{\mathrm{bc}}$ & $17.23 \pm 1.01^{\mathrm{b}}$ & $2.8 \pm 0.52^{\mathrm{b}}$ & $4.5 \pm 0.2^{\mathrm{c}}$ & $8.3 \pm 2.4^{\mathrm{ab}}$ & $2.71 \pm 0.73^{\mathrm{b}} \mathrm{c}$ & $0.33 \pm 0.6^{\mathrm{a}}$ & $0.41 \pm 0.4^{\mathrm{bc}}$ & $47.9 \pm 2.9 \mathrm{a}$ \\
\hline & 36 & $39.4 \pm 2.5^{\mathrm{b}}$ & $25.6 \pm 5.2^{\mathrm{b}}$ & $14.35 \pm 0.8^{\mathrm{c}}$ & $2.5 \pm 0.53^{\mathrm{c}}$ & $4.9 \pm 0.2^{\mathrm{b}}$ & $9.2 \pm 2.4^{\mathrm{ab}}$ & $2.24 \pm 0.56^{\text {cd }}$ & $0.36 \pm 0.7^{\mathrm{a}}$ & $0.49 \pm 0.4^{\mathrm{b}}$ & $52.3 \pm 3.1 \mathrm{a}$ \\
\hline & 48 & $46.5 \pm 2.7^{\mathrm{a}}$ & $30.4 \pm 4.5^{\mathrm{a}}$ & $13.33 \pm 0.5^{\mathrm{c}}$ & $2.2 \pm 0.44^{\mathrm{c}}$ & $5.3 \pm 0.2^{\mathrm{a}}$ & $10.5 \pm 2.9^{\mathrm{a}}$ & $2.19 \pm 0.57 \mathrm{~d}$ & $0.39 \pm 0.7 \mathrm{a}$ & $0.55 \pm 0.3^{\mathrm{a}}$ & $55.4 \pm 3.2 \mathrm{a}$ \\
\hline \multirow{4}{*}{ Ras } & 6 & $47.2 \pm 2.9 \mathrm{~d}$ & $33.8 \pm 1.5 \mathrm{~d}$ & $24.88 \pm 1.8 \mathrm{a}$ & $2.2 \pm 0.43 \mathrm{a}$ & $4.5 \pm 0.2 \mathrm{~b}$ & $5.6 \pm 1.4 \mathrm{~b}$ & $3.91 \pm 1.29 \mathrm{ab}$ & $0.19 \pm 0.1 \mathrm{~ns}$ & $0.31 \pm 0.6 \mathrm{~ns}$ & $62.7 \pm 3.5 \mathrm{~d}$ \\
\hline & 9 & $50.01 \pm 3.1 \mathrm{c}$ & $37.8 \pm 2.0 \mathrm{c}$ & $24.44 \pm 1.3 \mathrm{~b}$ & $2.1 \pm 0.42 \mathrm{ab}$ & $4.6 \pm 0.1 \mathrm{~b}$ & $6.7 \pm 1.5 \mathrm{ab}$ & $3.81 \pm 1.17 \mathrm{a}$ & $0.20 \pm 0.2 \mathrm{~ns}$ & $0.32 \pm 0.5 \mathrm{~ns}$ & $74.0 \pm 3.8 \mathrm{c}$ \\
\hline & 12 & $52.5 \pm 3.6 \mathrm{~b}$ & $42.5 \pm 2.4 \mathrm{~b}$ & $23.6 \pm 1.4 \mathrm{~b}$ & $2.0 \pm 0.34 \mathrm{bc}$ & $4.8 \pm 0.2 \mathrm{~b}$ & $7.3 \pm 1.7 \mathrm{a}$ & $3.71 \pm 1.35 b$ & $0.21 \pm 0.2 \mathrm{~ns}$ & $0.33 \pm 0.5 \mathrm{~ns}$ & $85.8 \pm 4.3 \mathrm{~b}$ \\
\hline & 24 & $58.3 \pm 3.8 \mathrm{a}$ & $48.3 \pm 3.1 \mathrm{a}$ & $21.05 \pm 1.0 \mathrm{c}$ & $1.85 \pm 0.23 \mathrm{c}$ & $5.2 \pm 0.1 \mathrm{a}$ & $6.8 \pm 1.9 \mathrm{a}$ & $3.31 \pm 1.42 \mathrm{~ns}$ & $0.25 \pm 0.4 \mathrm{~ns}$ & $0.39 \pm 0.7 \mathrm{~ns}$ & $92.7 \pm 4.5 \mathrm{a}$ \\
\hline \multirow{3}{*}{ Blue-viened } & 6 & $41.2 \pm 2.2 \mathrm{c}$ & $25.3 \pm 2.1 \mathrm{c}$ & $22.64 \pm 1.2 \mathrm{a}$ & $1.9 \pm 0.22 \mathrm{~b}$ & $4.9 \pm 0.3 \mathrm{~b}$ & $4.5 \pm 1.2 \mathrm{~b}$ & $3.55 \pm 1.47 \mathrm{~ns}$ & $0.20 \pm 0.2 \mathrm{~b}$ & $0.25 \pm 0.3 b$ & $45.6 \pm 2.7 \mathrm{c}$ \\
\hline & 9 & $44.5 \pm 2.4 \mathrm{~b}$ & $32.1 \pm 2.9 \mathrm{~b}$ & $21.69 \pm 1.1 \mathrm{~b}$ & $1.7 \pm 0.22 \mathrm{c}$ & $5.1 \pm 0.5 \mathrm{~b}$ & $4.8 \pm 1.5 \mathrm{ab}$ & $3.2 \pm 1.36 \mathrm{~ns}$ & $0.21 \pm 0.3 \mathrm{ab}$ & $0.24 \pm 0.4 \mathrm{~b}$ & $66.6 \pm 3.7 \mathrm{~b}$ \\
\hline & 12 & $48.8 \pm 2.8^{\mathrm{a}}$ & $38.4 \pm 3.6^{\mathrm{a}}$ & $20.41 \pm 1.1^{\mathrm{c}}$ & $2.8 \pm 0.34^{\mathrm{a}}$ & $5.8 \pm 0.2^{\mathrm{a}}$ & $5.7 \pm 1.7^{\mathrm{a}}$ & $3.4 \pm 1.38^{\text {ns }}$ & $0.24 \pm 0.4^{\mathrm{a}}$ & $0.34 \pm 0.5^{\mathrm{a}}$ & $74.5 \pm 3.9 \mathrm{a}$ \\
\hline
\end{tabular}

Averaged data of analyzed cheese samples in triplicate; Mean value \pm a standard deviation

Acidity is expressed as lactic acid. ${ }^{\text {aa }}$ Total Volatile Fatty Acids is expressed as $0.1 \mathrm{NNaOH} / 100 \mathrm{~g}$ cheese.

Table 2. Levels of biogenic amines ( $\mathrm{mg} / 100 \mathrm{~g}$ cheese) of Egyptian Cheese samples ripened/stored at different periods

\begin{tabular}{|c|c|c|c|c|c|c|c|c|c|c|}
\hline \multirow[b]{2}{*}{ Cheese types } & \multirow[b]{2}{*}{ Ripening/Storage period (mon) } & \multicolumn{9}{|c|}{ Biogenic amines $(\mathrm{mg} / 100 \mathrm{~g})$} \\
\hline & & Tyramine & Tryptamine & Putrescine & Histamine & Cadaverine & Spermidine & Spermine & $\begin{array}{c}\text { 2-Phenylethyl } \\
\text { amine }\end{array}$ & Total \\
\hline \multirow{5}{*}{ Mish } & 6 & $6 \pm 0.62^{\mathrm{e}}$ & $4 \pm 0.51^{\mathrm{d}}$ & $4 \pm 0.45^{\mathrm{d}}$ & $9 \pm 0.69^{\mathrm{e}}$ & $3 \pm 0.3^{\mathrm{e}}$ & $1 \pm 0.05^{\mathrm{d}}$ & $\mathrm{Nd}^{\mathrm{c}}$ & $\mathrm{Nd}^{\mathrm{d}}$ & $27 \pm 2.2$ \\
\hline & 12 & $12 \pm 1.35^{\mathrm{d}}$ & $10 \pm 0.85^{\mathrm{c}}$ & $10 \pm 0.85^{\mathrm{c}}$ & $14 \pm 0.98^{\mathrm{d}}$ & $10 \pm 0.5^{\mathrm{d}}$ & $1 \pm 0.11^{\mathrm{d}}$ & $\mathrm{Nd}^{\mathrm{c}}$ & $\mathrm{Nd}^{\mathrm{d}}$ & $57 \pm 3.2$ \\
\hline & 24 & $14 \pm 0.42^{\mathrm{c}}$ & $17 \pm 1.54^{\mathrm{b}}$ & $18 \pm 1.5^{\mathrm{b}}$ & $27 \pm 2.4^{\mathrm{c}}$ & $18 \pm 1.72^{\mathrm{c}}$ & $2 \pm 0.21^{\mathrm{c}}$ & $1 \pm 0.08^{\mathrm{b}}$ & $4 \pm 0.53^{\mathrm{c}}$ & $101 \pm 4.3$ \\
\hline & 36 & $15 \pm 0.46^{\mathrm{b}}$ & $21 \pm 1.79^{\mathrm{a}}$ & $19 \pm 1.7 \mathrm{a}^{\mathrm{b}}$ & $29 \pm 2.3^{\mathrm{b}}$ & $20 \pm 2.1^{\mathrm{b}}$ & $3 \pm 0.42^{\mathrm{b}}$ & $1 \pm 0.09^{\mathrm{b}}$ & $7 \pm 0.64^{\mathrm{b}}$ & $115 \pm 4.6$ \\
\hline & 48 & $19 \pm 1.55^{\mathrm{a}}$ & $22 \pm 2.15^{\mathrm{a}}$ & $20 \pm 2.16^{\mathrm{a}}$ & $31 \pm 2.5^{\mathrm{a}}$ & $22 \pm 1.97^{\mathrm{a}}$ & $4 \pm 0.63^{\mathrm{a}}$ & $2 \pm 0.16^{\mathrm{a}}$ & $12 \pm 1.15^{\mathrm{d}}$ & $132 \pm 5.3$ \\
\hline \multirow{4}{*}{ Ras } & 6 & $3 \pm 0.28^{\mathrm{d}}$ & $10 \pm 0.93^{\mathrm{b}}$ & $6 \pm 0.42^{\mathrm{d}}$ & $12 \pm 0.96^{\mathrm{d}}$ & $\mathrm{Nd}^{\mathrm{d}}$ & $1 \pm 0.08^{\mathrm{b}}$ & $\mathrm{Nd}^{\mathrm{b}}$ & $3 \pm 0.19^{\mathrm{b}}$ & $34 \pm 2.6$ \\
\hline & 9 & $4 \pm 0.54^{\mathrm{c}}$ & $11 \pm 1.05^{\mathrm{c}}$ & $8 \pm 0.62^{\mathrm{c}}$ & $14 \pm 0.91^{\mathrm{c}}$ & $8 \pm 0.71^{\mathrm{c}}$ & $1 \pm 0.11^{\mathrm{b}}$ & $\mathrm{Nd}^{\mathrm{b}}$ & $3 \pm 0.21^{\mathrm{b}}$ & $49 \pm 2.8$ \\
\hline & 12 & $5 \pm 0.61^{\mathrm{b}}$ & $13 \pm 1.13^{\mathrm{b}}$ & $13 \pm 0.54^{\mathrm{b}}$ & $23 \pm 2.05^{\mathrm{b}}$ & $13 \pm 1.26^{\mathrm{b}}$ & $\mathrm{Nd}^{\mathrm{c}}$ & $1 \pm 0.08^{\mathrm{a}}$ & $5 \pm 0.41^{\mathrm{a}}$ & $73 \pm 3.7$ \\
\hline & 24 & $14 \pm 1.07^{\mathrm{a}}$ & $20 \pm 1.86^{\mathrm{a}}$ & $16 \pm 1.25^{\mathrm{a}}$ & $26 \pm 2.4^{\mathrm{a}}$ & $20 \pm 2.1^{\mathrm{a}}$ & $2 \pm 0.21^{\mathrm{a}}$ & $\mathrm{Nd}^{\mathrm{b}}$ & $\mathrm{Nd}^{\mathrm{c}}$ & $98 \pm 4.1$ \\
\hline \multirow{3}{*}{ Blue-viened } & 6 & $\mathrm{Nd}^{\mathrm{c}}$ & $11 \pm 0.45^{\mathrm{c}}$ & $1 \pm 0.15^{\mathrm{c}}$ & $4 \pm 0.34^{\mathrm{c}}$ & $4 \pm 0.22^{\mathrm{c}}$ & $\mathrm{Nd}^{\mathrm{b}}$ & $\mathrm{Nd}^{\mathrm{b}}$ & $1 \pm 0.11^{\mathrm{c}}$ & $21 \pm 2.1$ \\
\hline & 9 & $1 \pm 0.1^{b}$ & $15 \pm 0.87^{b}$ & $2 \pm 0.31^{\mathrm{b}}$ & $9 \pm 0.94^{\mathrm{b}}$ & $7 \pm 0.65^{\mathrm{b}}$ & $\mathrm{Nd}^{\mathrm{b}}$ & $\mathrm{Nd}^{\mathrm{b}}$ & $2 \pm 0.25^{\mathrm{b}}$ & $36 \pm 2.6$ \\
\hline & 12 & $8 \pm 0.72^{\mathrm{a}}$ & $17 \pm 1.26^{\mathrm{a}}$ & $9 \pm 0.93^{\mathrm{a}}$ & $14 \pm 1.26^{\mathrm{a}}$ & $11 \pm 1.13^{\mathrm{a}}$ & $3 \pm 0.41^{\mathrm{a}}$ & $2 \pm 0.17^{\mathrm{a}}$ & $6 \pm 0.62^{\mathrm{a}}$ & $70 \pm 3.5$ \\
\hline
\end{tabular}

Averaged data of analyzed Cheese samples in triplicates, nd: not detected 
Table 3. Total amount of free amino acids content ( $\mathrm{mg} / \mathrm{g}$ dry weight of cheese) of Egyptian cheese ripened/stored at different periods

\begin{tabular}{|c|c|c|c|c|c|c|c|c|c|c|c|c|}
\hline \multirow{3}{*}{ Amino acids } & \multicolumn{5}{|c|}{ Mish cheese } & \multicolumn{4}{|c|}{ Ras cheese } & \multicolumn{3}{|c|}{ Blue cheese } \\
\hline & \multicolumn{12}{|c|}{ Ripening/Storage period (mon) } \\
\hline & 6 & 12 & 24 & 36 & 48 & 6 & 9 & 12 & 24 & 6 & 9 & 12 \\
\hline Threonine & $\begin{array}{l}1.38 \\
\pm 0.1 \\
\end{array}$ & $\begin{array}{c}1.36 \\
\pm 0.13 \\
\end{array}$ & $\begin{array}{c}1.38 \\
\pm 0.13 \\
\end{array}$ & $\begin{array}{c}1.20 \\
\pm 0.11 \\
\end{array}$ & $\begin{array}{l}1.18 \\
\pm 0.1 \\
\end{array}$ & $\begin{array}{l}1.18 \\
\pm 0.1 \\
\end{array}$ & $\begin{array}{l}1.32 \\
\pm 0.1 \\
\end{array}$ & $\begin{array}{l}1.38 \\
\pm 0.1 \\
\end{array}$ & $\begin{array}{l}1.28 \\
\pm 0.1 \\
\end{array}$ & $\begin{array}{l}1.28 \\
\pm 0.1 \\
\end{array}$ & $\begin{array}{l}1.18 \\
\pm 0.1 \\
\end{array}$ & $\begin{array}{l}1.12 \\
\pm 0.1 \\
\end{array}$ \\
\hline Serine & $\begin{array}{l}2.26 \\
\pm 0.2 \\
\end{array}$ & $\begin{array}{c}2.09 \\
\pm 0.23 \\
\end{array}$ & $\begin{array}{c}2.06 \\
\pm 0.23 \\
\end{array}$ & $\begin{array}{c}1.96 \\
\pm 0.23 \\
\end{array}$ & $\begin{array}{l}1.70 \\
\pm 0.2 \\
\end{array}$ & $\begin{array}{l}1.62 \\
\pm 0.2\end{array}$ & $\begin{array}{l}1.88 \\
\pm 0.2\end{array}$ & $\begin{array}{l}1.88 \\
\pm 0.3 \\
\end{array}$ & $\begin{array}{l}1.81 \\
\pm 0.3 \\
\end{array}$ & $\begin{array}{l}1.79 \\
\pm 0.2 \\
\end{array}$ & $\begin{array}{l}1.72 \\
\pm 0.2 \\
\end{array}$ & $\begin{array}{l}1.44 \\
\pm 0.1 \\
\end{array}$ \\
\hline Glutamic & $\begin{array}{l}8.52 \\
\pm 1.3 \\
\end{array}$ & $\begin{array}{l}8.21 \\
\pm 1.2 \\
\end{array}$ & $\begin{array}{l}8.19 \\
\pm 1.2 \\
\end{array}$ & $\begin{array}{l}6.50 \\
\pm 1.1 \\
\end{array}$ & $\begin{array}{l}5.76 \\
\pm 1.2 \\
\end{array}$ & $\begin{array}{l}9.96 \\
\pm 1.6 \\
\end{array}$ & $\begin{array}{l}6.63 \\
\pm 1.1 \\
\end{array}$ & $\begin{array}{l}5.54 \\
\pm 0.9 \\
\end{array}$ & $\begin{array}{c}5.46 \\
\pm 1 \\
\end{array}$ & $\begin{array}{l}8.66 \\
\pm 1.3 \\
\end{array}$ & $\begin{array}{l}8.60 \\
\pm 1.3 \\
\end{array}$ & $\begin{array}{c}5.34 \\
\pm 1 \\
\end{array}$ \\
\hline Proline & $\begin{array}{l}3.34 \\
\pm 0.3 \\
\end{array}$ & $\begin{array}{c}3.62 \\
\pm 0.34 \\
\end{array}$ & $\begin{array}{c}3.6 \\
\pm 0.34 \\
\end{array}$ & $\begin{array}{c}2.86 \\
\pm 0.12 \\
\end{array}$ & $\begin{array}{l}2.80 \\
\pm 0.2 \\
\end{array}$ & $\begin{array}{c}2.68 \\
\pm 0.24 \\
\end{array}$ & $\begin{array}{l}2.60 \\
\pm 0.3 \\
\end{array}$ & $\begin{array}{l}3.04 \\
\pm 0.3 \\
\end{array}$ & $\begin{array}{l}3.00 \\
\pm 0.3 \\
\end{array}$ & $\begin{array}{l}2.75 \\
\pm 0.3 \\
\end{array}$ & $\begin{array}{l}2.70 \\
\pm 0.3 \\
\end{array}$ & $\begin{array}{l}2.44 \\
\pm 0.3 \\
\end{array}$ \\
\hline Glycine & $\begin{array}{l}0.92 \\
\pm 0.1 \\
\end{array}$ & $\begin{array}{c}0.79 \\
\pm 0.11 \\
\end{array}$ & $\begin{array}{c}0.77 \\
\pm 0.11 \\
\end{array}$ & $\begin{array}{l}0.80 \\
\pm 0.1 \\
\end{array}$ & $\begin{array}{c}0.86 \\
\pm 0.09 \\
\end{array}$ & $\begin{array}{c}0.92 \\
\pm 0.11 \\
\end{array}$ & $\begin{array}{l}0.80 \\
\pm 0.1 \\
\end{array}$ & $\begin{array}{c}0.72 \\
\pm 0.08 \\
\end{array}$ & $\begin{array}{c}0.71 \\
\pm 0.08 \\
\end{array}$ & $\begin{array}{l}0.85 \\
\pm 0.1 \\
\end{array}$ & $\begin{array}{l}0.82 \\
\pm 0.1 \\
\end{array}$ & $\begin{array}{c}0.74 \\
\pm 0.08 \\
\end{array}$ \\
\hline Alanine & $\begin{array}{l}1.56 \\
\pm 0.1 \\
\end{array}$ & $\begin{array}{c}1.55 \\
\pm 0.19 \\
\end{array}$ & $\begin{array}{c}1.54 \\
\pm 0.19 \\
\end{array}$ & $\begin{array}{c}1.34 \\
\pm 0.13 \\
\end{array}$ & $\begin{array}{l}1.40 \\
\pm 0.1 \\
\end{array}$ & $\begin{array}{c}1.14 \\
\pm 0.13 \\
\end{array}$ & $\begin{array}{l}1.44 \\
\pm 0.1 \\
\end{array}$ & $\begin{array}{l}1.38 \\
\pm 0.1 \\
\end{array}$ & $\begin{array}{l}1.31 \\
\pm 0.1 \\
\end{array}$ & $\begin{array}{l}1.42 \\
\pm 0.1 \\
\end{array}$ & $\begin{array}{l}1.40 \\
\pm 0.1 \\
\end{array}$ & $\begin{array}{l}1.38 \\
\pm 0.1 \\
\end{array}$ \\
\hline Cysteine & $\begin{array}{c}0.18 \\
\pm 0.03 \\
\end{array}$ & $\begin{array}{c}0.18 \\
\pm 0.03 \\
\end{array}$ & $\begin{array}{c}0.18 \\
\pm 0.03 \\
\end{array}$ & $\begin{array}{c}0.16 \\
\pm 0.01 \\
\end{array}$ & $\begin{array}{c}0.14 \\
\pm 0.01 \\
\end{array}$ & $\begin{array}{c}0.16 \\
\pm 0.01 \\
\end{array}$ & $\begin{array}{c}0.17 \\
\pm 0.01 \\
\end{array}$ & $\begin{array}{c}0.16 \\
\pm 0.01 \\
\end{array}$ & $\begin{array}{c}0.16 \\
\pm 0.01 \\
\end{array}$ & $\begin{array}{c}0.26 \\
\pm 0.03 \\
\end{array}$ & $\begin{array}{c}0.21 \\
\pm 0.03 \\
\end{array}$ & $\begin{array}{c}0.15 \\
\pm 0.02 \\
\end{array}$ \\
\hline Valine & $\begin{array}{l}1.72 \\
\pm 0.2 \\
\end{array}$ & $\begin{array}{c}1.61 \\
\pm 0.22 \\
\end{array}$ & $\begin{array}{c}1.61 \\
\pm 0.22 \\
\end{array}$ & $\begin{array}{c}1.75 \\
\pm 0.17 \\
\end{array}$ & $\begin{array}{c}1.45 \\
\pm 0.12 \\
\end{array}$ & $\begin{array}{c}1.31 \\
\pm 0.12 \\
\end{array}$ & $\begin{array}{c}1.64 \\
\pm 0.15 \\
\end{array}$ & $\begin{array}{l}1.09 \\
\pm 0.1 \\
\end{array}$ & $\begin{array}{l}1.04 \\
\pm 0.1 \\
\end{array}$ & $\begin{array}{l}1.59 \\
\pm 0.1 \\
\end{array}$ & $\begin{array}{l}1.55 \\
\pm 0.1 \\
\end{array}$ & $\begin{array}{c}1.32 \\
\pm 0.11 \\
\end{array}$ \\
\hline Methionine & $\begin{array}{l}0.98 \\
\pm 0.1\end{array}$ & $\begin{array}{c}0.95 \\
\pm 0.14\end{array}$ & $\begin{array}{c}0.95 \\
\pm 0.14\end{array}$ & $\begin{array}{c}0.97 \\
\pm 0.11 \\
\end{array}$ & $\begin{array}{c}0.81 \\
\pm 0.07\end{array}$ & $\begin{array}{l}0.95 \\
\pm 0.1\end{array}$ & $\begin{array}{l}0.77 \\
\pm 0.1\end{array}$ & $\begin{array}{c}0.85 \\
\pm 0.07\end{array}$ & $\begin{array}{c}0.84 \\
\pm 0.07 \\
\end{array}$ & $\begin{array}{c}1.11 \\
\pm 0.15\end{array}$ & $\begin{array}{c}1.01 \\
\pm 0.15\end{array}$ & $\begin{array}{l}0.85 \\
\pm 0.1 \\
\end{array}$ \\
\hline Isoleucine & $\begin{array}{c}2.48 \\
\pm 0.22 \\
\end{array}$ & $\begin{array}{c}2.35 \\
\pm 0.31 \\
\end{array}$ & $\begin{array}{c}2.35 \\
\pm 0.31 \\
\end{array}$ & $\begin{array}{c}2.20 \\
\pm 0.15 \\
\end{array}$ & $\begin{array}{l}2.08 \\
\pm 0.2 \\
\end{array}$ & $\begin{array}{c}2.07 \\
\pm 0.21 \\
\end{array}$ & $\begin{array}{l}2.19 \\
\pm 0.2 \\
\end{array}$ & $\begin{array}{c}2.02 \\
\pm 0.17 \\
\end{array}$ & $\begin{array}{c}1.95 \\
\pm 0.17 \\
\end{array}$ & $\begin{array}{l}2.41 \\
\pm 0.3 \\
\end{array}$ & $\begin{array}{l}2.33 \\
\pm 0.3 \\
\end{array}$ & $\begin{array}{c}2.20 \\
\pm 0.19 \\
\end{array}$ \\
\hline Leucine & $\begin{array}{l}3.02 \\
\pm 0.3 \\
\end{array}$ & $\begin{array}{l}2.45 \\
\pm 0.3 \\
\end{array}$ & $\begin{array}{l}2.45 \\
\pm 0.3 \\
\end{array}$ & $\begin{array}{c}2.63 \\
\pm 0.23 \\
\end{array}$ & $\begin{array}{c}2.40 \\
\pm 0.16 \\
\end{array}$ & $\begin{array}{c}2.22 \\
\pm 0.23 \\
\end{array}$ & $\begin{array}{c}2.48 \\
\pm 0.22 \\
\end{array}$ & $\begin{array}{c}2.18 \\
\pm 0.15 \\
\end{array}$ & $\begin{array}{c}2.11 \\
\pm 0.15 \\
\end{array}$ & $\begin{array}{l}2.73 \\
\pm 0.3 \\
\end{array}$ & $\begin{array}{l}2.66 \\
\pm 0.3 \\
\end{array}$ & $\begin{array}{c}2.35 \\
\pm 0.18 \\
\end{array}$ \\
\hline Tyrosine & $\begin{array}{l}2.06 \\
\pm 0.2 \\
\end{array}$ & $\begin{array}{l}1.87 \\
\pm 0.2 \\
\end{array}$ & $\begin{array}{l}1.85 \\
\pm 0.2 \\
\end{array}$ & $\begin{array}{c}1.42 \\
\pm 0.14 \\
\end{array}$ & $\begin{array}{l}1.67 \\
\pm 0.1 \\
\end{array}$ & $\begin{array}{c}1.52 \\
\pm 0.13 \\
\end{array}$ & $\begin{array}{c}1.74 \\
\pm 0.12 \\
\end{array}$ & $\begin{array}{l}1.55 \\
\pm 0.1 \\
\end{array}$ & $\begin{array}{l}1.53 \\
\pm 0.1 \\
\end{array}$ & $\begin{array}{c}1.98 \\
\pm 0.2 \\
\end{array}$ & $\begin{array}{l}1.94 \\
\pm 0.2 \\
\end{array}$ & $\begin{array}{l}1.74 \\
\pm 0.1 \\
\end{array}$ \\
\hline $\begin{array}{c}\text { Phenylalanin } \\
\text { e }\end{array}$ & $\begin{array}{l}1.72 \\
\pm 0.2 \\
\end{array}$ & $\begin{array}{c}1.88 \\
\pm 0.22 \\
\end{array}$ & $\begin{array}{c}1.86 \\
\pm 0.22 \\
\end{array}$ & $\begin{array}{c}1.17 \\
\pm 0.11 \\
\end{array}$ & $\begin{array}{l}1.48 \\
\pm 0.1 \\
\end{array}$ & $\begin{array}{c}1.31 \\
\pm 0.12 \\
\end{array}$ & $\begin{array}{l}1.53 \\
\pm 0.1 \\
\end{array}$ & $\begin{array}{c}1.39 \\
\pm 0.11 \\
\end{array}$ & $\begin{array}{c}1.36 \\
\pm 0.11 \\
\end{array}$ & $\begin{array}{l}1.73 \\
\pm 0.2 \\
\end{array}$ & $\begin{array}{l}1.66 \\
\pm 0.2 \\
\end{array}$ & $\begin{array}{l}1.54 \\
\pm 0.1 \\
\end{array}$ \\
\hline Histidine & $\begin{array}{l}1.80 \\
\pm 0.2 \\
\end{array}$ & $\begin{array}{c}1.94 \\
\pm 0.23\end{array}$ & $\begin{array}{c}1.91 \\
\pm 0.23\end{array}$ & $\begin{array}{c}1.55 \\
\pm 0.25\end{array}$ & $\begin{array}{l}1.83 \\
\pm 0.2 \\
\end{array}$ & $\begin{array}{c}1.47 \\
\pm 0.11\end{array}$ & $\begin{array}{c}1.68 \\
\pm 0.12\end{array}$ & $\begin{array}{c}1.57 \\
\pm 0.11\end{array}$ & $\begin{array}{c}1.56 \\
\pm 0.11 \\
\end{array}$ & $\begin{array}{l}1.82 \\
\pm 0.2 \\
\end{array}$ & $\begin{array}{l}1.79 \\
\pm 0.2 \\
\end{array}$ & $\begin{array}{l}1.60 \\
\pm 0.1\end{array}$ \\
\hline Lysine & $\begin{array}{l}1.12 \\
\pm 0.1 \\
\end{array}$ & $\begin{array}{c}0.99 \\
\pm 0.17 \\
\end{array}$ & $\begin{array}{c}0.95 \\
\pm 0.17 \\
\end{array}$ & $\begin{array}{c}0.77 \\
\pm 0.09 \\
\end{array}$ & $\begin{array}{l}0.85 \\
\pm 0.1 \\
\end{array}$ & $\begin{array}{c}0.66 \\
\pm 0.02 \\
\end{array}$ & $\begin{array}{c}0.78 \\
\pm 0.06 \\
\end{array}$ & $\begin{array}{c}0.80 \\
\pm 0.08 \\
\end{array}$ & $\begin{array}{c}0.78 \\
\pm 0.08 \\
\end{array}$ & $\begin{array}{l}0.92 \\
\pm 0.1\end{array}$ & $\begin{array}{l}0.87 \\
\pm 0.1 \\
\end{array}$ & $\begin{array}{l}0.81 \\
\pm 0.1 \\
\end{array}$ \\
\hline Tryptophan & $\begin{array}{l}0.94 \\
\pm 0.1\end{array}$ & $\begin{array}{c}0.98 \\
\pm 0.16\end{array}$ & $\begin{array}{c}0.95 \\
\pm 0.16\end{array}$ & $\begin{array}{l}0.83 \\
\pm 0.1 \\
\end{array}$ & $\begin{array}{c}0.79 \\
\pm 0.08\end{array}$ & $\begin{array}{c}0.73 \\
\pm 0.11\end{array}$ & $\begin{array}{c}0.79 \\
\pm 0.07\end{array}$ & $\begin{array}{l}0.85 \\
\pm 0.1\end{array}$ & $\begin{array}{l}0.82 \\
\pm 0.1\end{array}$ & $\begin{array}{c}0.99 \\
\pm 0.11\end{array}$ & $\begin{array}{c}0.95 \\
\pm 0.11\end{array}$ & $\begin{array}{l}0.91 \\
\pm 0.1\end{array}$ \\
\hline Arginine & $\begin{array}{l}1.10 \\
\pm 0.1 \\
\end{array}$ & $\begin{array}{c}1.11 \\
\pm 0.16 \\
\end{array}$ & $\begin{array}{c}1.01 \\
\pm 0.16 \\
\end{array}$ & $\begin{array}{c}1.15 \\
\pm 0.13 \\
\end{array}$ & $\begin{array}{c}0.78 \\
\pm 0.09 \\
\end{array}$ & $\begin{array}{c}0.82 \\
\pm 0.12 \\
\end{array}$ & $\begin{array}{l}0.75 \\
\pm 0.1 \\
\end{array}$ & $\begin{array}{l}0.78 \\
\pm 0.1 \\
\end{array}$ & $\begin{array}{l}0.75 \\
\pm 0.1 \\
\end{array}$ & $\begin{array}{c}0.83 \\
\pm 0.09 \\
\end{array}$ & $\begin{array}{c}0.79 \\
\pm 0.09 \\
\end{array}$ & $\begin{array}{c}0.69 \\
\pm 0.05 \\
\end{array}$ \\
\hline Total & $\begin{array}{c}35.10 \\
\pm 3.3 \\
\end{array}$ & $\begin{array}{c}33.93 \\
\pm 2.9 \\
\end{array}$ & $\begin{array}{c}33.61 \\
\pm 2.9 \\
\end{array}$ & $\begin{array}{l}29.26 \\
\pm 2.7 \\
\end{array}$ & $\begin{array}{c}27.98 \\
\pm 2.6 \\
\end{array}$ & $\begin{array}{l}30.08 \\
\pm 1.9 \\
\end{array}$ & $\begin{array}{l}29.19 \\
\pm 2.5 \\
\end{array}$ & $\begin{array}{c}27.18 \\
\pm 2.9 \\
\end{array}$ & $\begin{array}{c}25.74 \\
\pm 3.0 \\
\end{array}$ & $\begin{array}{c}33.12 \\
\pm 3.1 \\
\end{array}$ & $\begin{array}{l}32.3 \\
\pm 3.1 \\
\end{array}$ & $\begin{array}{c}26.62 \\
\pm 2.8 \\
\end{array}$ \\
\hline
\end{tabular}

Averaged data of analyzed Cheese samples in triplicates.

Table 4. Means counts of microorganisms in Egyptian market cheeses

\begin{tabular}{|c|c|c|c|c|c|c|c|}
\hline Cheese types & $\begin{array}{l}\text { Ripening/storage } \\
\text { period (mon) }\end{array}$ & $\begin{array}{c}\text { Aerobic } \\
\text { mesophilic } \\
\text { bacteria }\left(10^{6}\right. \\
\text { cfu/g) }\end{array}$ & $\begin{array}{l}\text { Coliform } \\
\text { group } \\
\left(10^{2} \mathrm{cfu} / \mathrm{g}\right)\end{array}$ & $\begin{array}{l}\text { Moulds \& } \\
\text { Yeasts } \\
\left(10^{3} \mathrm{cfu} / \mathrm{g}\right)\end{array}$ & $\begin{array}{l}\text { Lactococci } \\
\left(10^{4} \mathrm{cfu} / \mathrm{g}\right)\end{array}$ & $\begin{array}{l}\text { Enterococci } \\
\left(10^{4} \mathrm{cfu} / \mathrm{g}\right)\end{array}$ & $\begin{array}{c}\text { Lactic acid } \\
\text { bacteria } \\
\left(10^{6} \mathrm{cfu} / \mathrm{g}\right)\end{array}$ \\
\hline \multirow{5}{*}{ Mish } & 6 & $7.59 \pm 0.13^{b}$ & $4.98 \pm .15^{\mathrm{ef}}$ & $3.89 \pm 0.21^{\mathrm{f}}$ & $7.13 \pm 0.19^{\mathrm{a}}$ & $6.45 \pm 0.22^{\mathrm{a}}$ & $10.24 \pm 0.09^{\mathrm{a}}$ \\
\hline & 12 & $7.37 \pm 0.42 b^{c}$ & $5.07 \pm .44^{\mathrm{de}}$ & $4.05 \pm 0.20^{\mathrm{ef}}$ & $6.94 \pm 0.31^{\mathrm{b}}$ & $6.38 \pm 0.87^{\mathrm{b}}$ & $9.66 \pm 0.12^{b}$ \\
\hline & 24 & $6.84 \pm 0.06^{\mathrm{fg}}$ & $5.27 \pm .59^{\text {cde }}$ & $4.33 \pm 0.63^{\mathrm{de}}$ & $6.75 \pm 0.18^{c}$ & $6.33 \pm .44^{\mathrm{bc}}$ & $9.50 \pm 0.17^{\mathrm{bc}}$ \\
\hline & 36 & $6.28 \pm 0.04^{i}$ & $5.34 \pm .57^{\mathrm{cd}}$ & $4.74 \pm 0.90^{\mathrm{c}}$ & $6.66 \pm .06^{\mathrm{cde}}$ & $6.13 \pm 0.54^{\mathrm{c}}$ & $9.23 \pm 0.08^{\text {def }}$ \\
\hline & 48 & $6.09 \pm 0.18^{\mathrm{i}}$ & $5.53 \pm .35^{\mathrm{bc}}$ & $4.82 \pm 0.42^{\mathrm{c}}$ & $6.34 \pm 0.37^{\mathrm{f}}$ & $5.88 \pm 0.30^{\mathrm{d}}$ & $9.15 \pm 0.13^{\text {ef }}$ \\
\hline \multirow{4}{*}{ Ras } & 6 & $7.13 \pm 0.20^{\mathrm{de}}$ & $4.5 \pm 0.23^{\mathrm{g}}$ & $4.05 \pm 0.20^{\mathrm{ef}}$ & $6.67 \pm 0.20^{\mathrm{cd}}$ & $5.82 \pm 0.18^{\mathrm{de}}$ & $9.65 \pm 0.20^{\mathrm{b}}$ \\
\hline & 9 & $6.95 \pm 0.24^{\mathrm{ef}}$ & $4.63 \pm 0.21^{\mathrm{g}}$ & $4.37 \pm 0.43^{\mathrm{d}}$ & $6.58 \pm .17^{\mathrm{de}}$ & $5.78 \pm .39^{\mathrm{de}}$ & $9.55 \pm 0.13^{\mathrm{bc}}$ \\
\hline & 12 & $6.65 \pm 0.21^{\mathrm{gh}}$ & $4.72 \pm .42^{\mathrm{gf}}$ & $4.79 \pm 0.61^{\mathrm{c}}$ & $6.50 \pm .13^{\mathrm{ef}}$ & $5.73 \pm .47^{\mathrm{de}}$ & $9.30 \pm 0.11^{\mathrm{de}}$ \\
\hline & 24 & $6.51 \pm 0.18^{\mathrm{h}}$ & $3.93 \pm 0.23^{\mathrm{h}}$ & $5.01 \pm 0.39^{\mathrm{bc}}$ & $6.40 \pm 0.19^{f}$ & $5.63 \pm 0.38^{\mathrm{e}}$ & $9.13 \pm 0.07^{\mathrm{ef}}$ \\
\hline \multirow{3}{*}{ Blue-viened } & 6 & $7.92 \pm 0.24^{\mathrm{a}}$ & $5.84 \pm 0.25^{\mathrm{a}}$ & $4.82 \pm 0.42^{\mathrm{c}}$ & $4.51 \pm 0.14^{\mathrm{g}}$ & $5.88 \pm 0.41^{\mathrm{d}}$ & $9.36 \pm 0.011^{\text {cd }}$ \\
\hline & 9 & $7.37 \pm 0.21^{\mathrm{bc}}$ & $5.65 \pm .26^{\mathrm{ab}}$ & $5.23 \pm 0.16^{\mathrm{ab}}$ & $4.38 \pm 0.21^{\mathrm{g}}$ & $5.78 \pm .44^{\mathrm{de}}$ & $9.30 \pm 0.06^{\mathrm{de}}$ \\
\hline & 12 & $7.22 \pm 0.58^{\text {ed }}$ & $5.27 \pm .19^{\text {cde }}$ & $5.37 \pm 0.39^{\mathrm{a}}$ & $4.00 \pm 0.09^{\mathrm{h}}$ & $5.73 \pm .30^{\mathrm{de}}$ & $9.08 \pm 0.08^{f}$ \\
\hline
\end{tabular}

Microbiological composition of Egyptian market cheeses (means $\pm \mathrm{SD}$ ). Means log counts in triplicates. 


\subsection{Microbiological Evaluation}

Microbiological analyses of the Egyptian cheeses were examined throughout ripening / storage period (Table 4). Lactic acid bacteria did not show any substantial change during storage period, while the numbers of Enterobacteriaceae remained high during the ripening/storage period, despite of a slight decrease at the end of ripening period. All of bacterial groups except for coliforms were at maximum in young cheeses. Numbers of Lactococcus sp were slightly higher than those of lactobacilli and total mesophilic bacteria. The difference of Lactococci counts from the other groups was maximum three log units. The predominance of Lactococcus $s p$ during the early stages of raw milk cheeses ripening was reported [Manolopoulou et al., 2003]. Lactic acid bacteria (i.e., Lactococci, Lactobacilli and Enterococci) were quantitatively the dominant groups, and change of their viable numbers was significant $(\mathrm{P} \leq 0: 01)$ throughout the ripening period. Numbers of Enterococcus sp. in all samples of Ras cheese were almost the same in Blue cheese. The presence of Enterococci $s p$. in high numbers could be due to their tolerance to a wide range of environmental conditions such as low temperature, high salt content and acidity [Garg \& Mital, 1992]. Because of these properties, although all microorganisms were effected from salt significantly $(\mathrm{P} \leq 0: 05)$, Enterococcus $s p$. were not. Enterococci are a group of microorganisms that may influence the ripening process due to their proteolytic and lipolytic activities and their ability to stimulate acid production by some Lactococci [Sarantinopoulos et al., 2001]. Total mesophilic aerobic bacteria increased reaching their highest numbers during a 45-day ripening period at cold storage, and then rapidly declined. Numbers of microorganisms indicative of the hygienic quality, such as coliforms, Enterococcus sp and Lactococcus $s p$ were present in cheese at relatively high levels. These counts suggest that contamination was very high in raw milk. Numbers of coliforms and Enterococcus sp. were not reduced significantly $(\mathrm{P} \leq 0: 05)$, while numbers of Lactobacilli $s p$. were also reduced significantly depending on the ripening time $(\mathrm{P} \leq 0: 01)$, but they remained alive. This can be explained by the $\mathrm{pH}$ levels and the quantity of lactic acid. Counts of yeasts and moulds were in Mish cheese similar to other findings in Ras cheeses. During the ripening/storage period the numbers were not significantly decreased $(\mathrm{P} \leq 0: 01)$, and they had relatively high counts in Blue cheeses. Yeasts were present at various levels among the distinct cheeses, grouped from dairy markets, the differences in numbers may be due to the distinct $\mathrm{pH}$ and salt concentrations found between the corresponding cheeses, although no significant correlations resulted. Occurrence of yeasts in cheeses was variable, because they have been associated with the production of flavour compounds as a result of their relatively strong proteolytic and lipolytic activities. However, scant information is available regarding the contribution of yeasts to synthesis of BAs in foods: a histidine-decarboxylase activity was found in yeasts of the genera Debaromyces and Candida isolated from fermented meat [Montel et al. 1999] and such an activity was actually above that observed in lactic acid bacteria. Macedo et al. [1995] found that the presence of yeasts was closely related to lactic acid utilization, while their contribution to the ripening process was due to their proteolytic and lipolytic activities. In this study, the number of microorganisms such as yeasts, moulds, and coliforms causing spoilage of cheeses by their putrefactive effects were decreased slightly. Formation of basic compounds from proteolysis could be cause changing of $\mathrm{pH}$ and a decrease of acidity. As recommendation, the permissible level of biogenic amines stipulated by Egyptian Organization for Standardization and Quality Control [EOS, 1996] should be modified to meet the more safe standard adopted by Food Drug Administration [FDA, 2001] and their levels can be lowered by using of good quality raw milk and maintaining hygiene standards during manufacturing and storage processes.

\section{Conclusions}

The main feature influencing the BAs formation is the extent of growth of microorganisms, like Enterococci sp. characterized by decarboxylase activity. The presence of high contents of BAs in Mish and Ras cheeses could be related to the enzymatic activity of proteases derived from microorganisms, or from another factor, that is important from a qualitative point of view, i.e., in relation to the type of amino acids provided to the amino acid decarboxylating microbiota, in particular tyrosine. Therefore, a large amount of BAs in cheese reflects the bad hygienic conditions under which they produced and stored. Accordingly, the levels of biogenic amines in different cheeses should be come in accordance with the safe permissible limit recommended by FDA to ensure human safety.

\section{REFERENCES}

[1] AOAC. Association of Official Analytical Chemists. Official methods of analysis $\left(17^{\text {th }}\right.$ Ed). 2002, Arlington, Virginia, USA: Association of Official Analytical Chemists, International, Inc.

[2] Alberto M.R., Arena M.E. Manca de Nadra, M.C., A comparative survey of two analytical methods for identification and quantification of biogenic amines. 2002, Food Control, 13, 125-129.

[3] Bütikofer U., Fuchs D., Development of free amino acids in cheese. 1997, Le Lait, 77, 91-100.

[4] Caston J.C., Eaton C.L., Gheorghui B.P., Ware L.L., Tyramine induced hypertensive episodes, panic attacks in hereditary deficient monoamine oxidase patients: case reports.2002, J.S.C. Med. Assoc., 98, 187-192.

[5] Chang S.F., Ayres J.W., Sandine W.E., Analysis of cheese 
for histamine, tyramine, tryptamine, histidine, tyrosine and tryptophan. 1985, Journal of Dairy Science, 68, 284-2846.

[6] Cogan T.M., Barbosa, M., Beuvier, E., Bianchi-Salvadori, B., Cocconcelli, P.S., Fernandes, I., Gomez, J., Gomez R., Kalan Tzopoulos G., Ledda A., Medina M., Rea M.C., Rodriguez E., Characterization of the lactic acid bacteria in artisanal dairy products. 1997, Journal of Dairy Researches, 64, 409-421.

[7] EOS. Egyptian Organization for Standardization and Quality Control. Detection of poisons and control, Report. 1996, pp: 1796.

[8] FDA, Food Drug Administration. Food and drug administration hazards and controls. 2001, Guidance, $3^{\text {rd }}$ ed. Center of food safety and Nutrition, Washington, USA.

[9] Fernández M., Linares D., Del Río B., Ladero V., Alvarez M.A., HPLC quantification of biogenic amines in cheeses: correlation with PCR-detection of tyramine-producing microorganisms. 2007, Journal of Dairy Researches, 74, 276-282.

[10] Frank J.F., Christen G.L., Bullerman L.B., Tests for groups of microorganisms. 1993, In: Marshall, R (Ed.), Standard Methods for the Examination of Dairy Products, $16^{\text {th }}$ ed. American Public Health Association, Washington DC, pp. 271-286.

[11] Furtado M.M., Partridge J.A., Characterization of nitrogen fractions during ripening of a soft cheese made from ultra filtration retentates.1988, Journal of Dairy Science, 71, 1379-1400.

[12] Galgano F., Suzzi G., Favati F., Caruso M., Martuscelli M., Gardini F., Salzano G., Biogenic amines during ripening in "Semicotto Caprino" cheese: role of enterococci. 2001, Int. J. Food Sci. \& Tech., 36, 153-160.

[13] Garg S.K., Mital B.K., Enterococci in milk and milk products. 1992, Critical Reviews in Microbiology, 18, $15-45$.

[14] Halász A., Barath A., Simon-Sarkadi L., Holzhapeel W., Biogenic amines and their production by microorganisms in food. 1994, Trends in Food Science \& Technology, 5, $42-46$.

[15] Ibrahim A., Amer A., Comparison of biogenic amines levels in different processed cheese varieties with regulatory specifications. 2010, World J. of Dairy and Food Sci., 5, 127-133.

[16] IDF. International Dairy Federation. Determination of nitrogen content. 1993, Standard 20 B. Brussels, Belgium.

[17] Izquierdo E., Marchioni E., Aoude-Werner D., Hasselmann C., Ennahar S., Smearing of soft cheese with Enterococcus faecium WHE81, a multi bacteriocins producer, against Listeria monocytogenes. 2009, Food Microbiology, 26, 16-20

[18] Joosten H.M.L.J., Conditions allowing the formation of biogenic amines in cheese: 3 Factors influencing the amounts formed. 1988, Netherlands milk and dairy journal, 41, 329-357.

[19] Joosten H.M.L.J., Northolt M.D., Conditions allowing the formation of biogenic amines in cheese. 1. Decarboxylative properties of some non-starter bacteria. 1987, Netherlands milk and dairy journal, 41, 259-280.

[20] Kayser F. H., Safety aspects of enterococci from the medical point of view. 2003, Int. J. Food Microb, 88, 255-262.

[21] Kebary K.K., El-Sonbaty A.H., Badawi R.M., Effects of heating milk and accelerating ripening of low fat Ras cheese on biogenic amines and free amino acids development. 1999, Food Chemistry, 64 (1), 67-75.

[22] Khan H., Flint S., Yu P.L., Enterocins in food preservation. 2010, Int. J. Food Microb., 141, 1-10.

[23] Komprda T., Burdychova R., Dohnal V., Cwikova' O., Sla'dkova' P., Dvora'ckova H. Tyramine production in Dutch-type semi-hard cheese from two different producers. 2008, Food Microbiology, 25, 219-227.

[24] Krause I., Bockhardt A., Neckermann H., Henle T., Klostermeyer H., Simultaneous determination of amino acids and biogenic amines by reversed-phase high performance liquid chromatography of the dabsyl derivatives. 1995, Journal of Chromatography A, 715, $67-79$.

[25] Krause I., Bockhardt A., Klostermeyer H., Characterization of cheese ripening by free amino acids and biogenic amines and influence of bactofugation and heat-treatment of milk. 1997, Le Lait, 77, 101-108.

[26] Kuchroo C.N., Fox P.F., Soluble nitrogen in Cheddar cheese: comparison of extraction procedures. 1982, Milchwissenschaft, 37, 331-335.

[27] Kung H.F., Lee Y.H., Chang S.C., Wei C.I., Tsai Y. H. Histamine contents and histamine-forming bacteria in sufu products in Taiwan. 2007, Food Control, 18, 381-386.

[28] Ladero V., Calles-Enríquez M., Fernández M., Alvarez M.A., Toxicological effects of dietary biogenic amines. 2010, Current Nutrition Food Science, 6, 145-156.

[29] Ladero V., Fernández M., Alvarez M.A., Effect of post-ripening processing on the histamine and histamine-producing bacteria contents of different cheeses. 2009, Int. Dairy J., 19, 759-762.

[30] Liu R.X., Kuang J., Gong Q., Hou X.L., Principal component regression analysis with spps. 2003, Computer Methods and Programs in Biomedicine, 71, 41-47.

[31] Loizzo M.R., Menichini F., Picci N., Puoci F., Spizzirri G., Restuccia D., Technological aspects and analytical determination of biogenic amines in cheese. 2012, Trends in Food Science Technology, xx, 1-18.

[32] Macedo A.C., Malcata F.X., Hogg T.A., Microbiological profile in Sera ewe's cheese during ripening. 1995, J. Appl. Bacterio., 79, 1-11.

[33] Maijala R., Histamine and tyramine production by a Lactobacillus strain subjected to external $\mathrm{pH}$ decrease. 1994, Journal of Food Protection, 57, 259-262.

[34] Manolopoulou E., Sarantinopoulos P., Zoidou E., Aktypis A., Moschopoulou E., Kandarakis I.G., Anifantakis E.M., Evolution of microbial populations during traditional Feta cheese manufacture and ripening. 2003, Int. J. Food Microb., 82, 153-161. 
[35] Martuscelli, M., Gardini, F., Torriani, S., Mastrocola, D., Serio, A., Chaves-Lopez, C., Schirone M., Suzzi G., Production of biogenic amines during the ripening of Pecorino Abruzzese cheese. 2005, Int. Dairy J., 15, 571-578.

[36] Mercogliano R., De Felice A., Chirollo C., Cortesi M.L., Production of vasoactive amines during the ripening of Pecorino Carmasciano cheese. 2010, Veterinary Res. Communications, 34, 175-178.

[37] Messer J.W., Behney H.M., Leudecke L.O., Microbiological count methods. 1985, In: Richardson, GH (Ed.), Standard Methods for the Examination of Dairy Products, $15^{\text {th }}$ Ed. APHA, Washington, DC, USA, pp, 133-149.

[38] Mohamed A.G, Deabes M.M., Fatma A.M. Hassan A., Enab K., Abou- Arab A.A.K., Biogenic amines and chemical composition of different formulations used for manufacture of processed cheese. 2013, J. Appl. Sci. Res., 9 (3), 1477-1483.

[39] Montel, M.C., Masson, F., Talon, R. (1999). Comparison of biogenic amine content in traditional and industrial French dry sausages. Sciences des Aliments, 19, 247-254.

[40] Novella-Rodriguez, S., Vegianan-Nogues, M.T., Truillo-Mesa, A.J., Vidal-Carou, M.C. (2002). Profile of biogenic amines in goat cheese made from pasteurized and pressurized milk. Journal of Food Science, 67, 2940-2944.

[41] Ordonez J.A., Ibanez F.C., Torre P., Barcina Y., Formation of biogenic amines in Idiazabal ewe's-milk cheese: effect of ripening, pasteurization, and starter. 1997, Journal of Food Protection, 60, 1371-1375.

[42] Pinho O., Ferreira I.O., Mendes E., Oliviera B.M., Ferreira M., Effect of temperature on evolution of free amino acid and biogenic amine contents during storage of Azeitao cheese. 2001, Food Chemistry, 75, 287-291.

[43] Pintado A.I.E., Pinho O., Ferreira I.O., Pintado M., Gomes A., Malcata F., (2008). Microbiological, biochemical and biogenic amine profiles of Terrincho cheese manufactured in several dairy farms. 2008, Int. Dairy J., 18, 631-640.
[44] Repka-Ramírez M.S., Baraniuk J.N. Histamine in health and disease. 2002, J. Allergy Clinical Immunology, 17, $1-25$.

[45] Sarantinopoulos P., Andrighetto C., Georgalaki M.D., Rea M.C., Lombardi A., Cogan T.M., Kalantzopoulos G., Tsakalidou E., Biochemical properties of enterococci relevant to their technological performance. 2001, Int. Dairy J., 11, 621-647.

[46] Schirone M., Tofalo R., Mazzone G., Corsetti A., Suzzi G., Biogenic amine content and microbiological profile of Pecorino di-Farindola cheese. 2011, Food Microbiology, $28,128-136$.

[47] Smit G., Smit B.A., Engels W.J.M., Flavour formation by lactic acid bacteria and biochemical flavour profiling of cheese products. 2005, FEMS Microbiology Reviews, 29, 591-610.

[48] Spanjer M.C., Van Roode B.A.S.W., Towards a regulatory limit for biogenic amines in fish, cheese and sauerkraut. 1991, De Ware (n)-Chemicus, 21, 139-167.

[49] Stratton, S.S., Hutkins, R.W., Taylor, S.L. (1991). Biogenic amines in cheese and other fermented foods: a review. Journal of Food Protection, 54, 460-470.

[50] Sumner S.S., Taylor S.L., Detection method for histamine producing dairy-related bacteria using di-amine oxidase and leucocrystal violet. 1989, J. Food Protection, 52, 105-108.

[51] Suzzi G., Gardini F., Biogenic amines in dry fermented sausages: a review. 2003, Int. J. Food Microb., 88, 41-54.

[52] Taylor S.L., Histamine Poisoning Associated with Fish, Cheese and Other Foods. 1985, World Health Organization, Geneva, Switzerland, pp. 1-47.

[53] Ten Brink B., Damink C., Joosten H.M.L.J., Huisint-Veld J.H.J., Occurrence and formation of biologically active amines in foods. 1990, Int. J. Food Microb., 11, 73-84.

[54] Wöhrl S., Hemmer W., Focke M., Rappersberger K., Jarisch R., Histamine intolerance-like symptoms in healthy volunteers after oral provocation with liquid histamine. 2004, Allergy and Asthma Proceedings, 25, 305-311. 